\title{
Migration Patterns and Phenotypic Diversity of Underyearlings of Sockeye Salmon Oncorhynchus nerka in the Ozernaya River Basin (Kamchatka)
}

\author{
E. A. Kirillova*, P. I. Kirillov, D. S. Pavlov, and A. O. Zvezdin \\ Severtsov Institute of Ecology and Evolution, Russian Academy of Sciences, Moscow, Russia \\ *e-mail: ekirillova@sevin.ru \\ Received February 27, 2017
}

\begin{abstract}
Migratory behavior, size composition, and feeding patterns of the underyearlings of sockeye salmon Oncorhynchus nerka from different intraspecific phenotypic groups in the Ozernaya River basin are studied. Complex organization of main phenotypic groups is demonstrated: several labile spatial-temporal groups are defined within them. The discovered phenotypic polymorphism is temporal and manifested by the sockeye salmon underyearlings only during the period in which they reach the main rearing grounds.
\end{abstract}

Keywords: sockeye salmon Oncorhynchus nerka, underyearlings, distribution, downstream migration, phenotypic diversity, Ozernaya River, Lake Kurilskoye

DOI: $10.1134 / \mathrm{S} 0032945217060091$

Sockeye salmon Oncorhynchus nerka is the only species of Pacific salmon specialized on reproduction in lake and river systems (Quinn, 2005; Bugaev and Kirichenko, 2008). The most abundant populations of sockeye salmon inhabit lakes of the Asian and American coasts of the Pacific Ocean. Lake Kurilskoye (Ozernaya River Basin), located on the southern Kamchatka Peninsula, is the spawning and rearing reservoir for the largest population of sockeye salmon in Asia (the so-called Ozernovskaya population).

The geomorphological features of lake and river systems determine the wide variety of reproductive conditions of the species. The sockeye salmon spawning grounds are located both in the lakes themselves and in the rivers that flow in and out of them. In the Ozernaya River Basin, which includes Lake Kurilskoye, the sockeye salmon spawning grounds are represented by three types: limnetic (littoral) make up $71 \%$ of the spawning area; riverine (in lake tributaries and the river flowing from the lake), $26 \%$; and spring brooks, 3\% (Ostroumov, 1970). In the first summer of life, juveniles from spawning grounds of all types move to the pelagic zone of the lake to the rearing area (Krokhin and Krogius, 1937; Smirnov, 1975; Bugaev, 1995).

After emergence from the ground, juveniles come under influence of various conditions (presence and direction of currents, temperature and feeding conditions) depending on the location of the spawning grounds in relation to the rearing reservoir. Therefore, to reach the rearing area, juveniles undertake migrations of varying direction, distance, and duration. For the sockeye salmon underyearlings of the Ozernaya River Basin, three types of migrations from the spawning grounds are typical: downstream migration from lake tributaries and partially in the Ozernaya River; upstream from the riverine spawning areas of the Ozernaya River; movement of juveniles from the littoral of the lake to the pelagic zone (Krokhin and Krogius, 1937; Egorova, 1970; Bugaev et al., 2009; Kirillova, etc., 2010; Kirillova and Pavlov, 2011).

The variety of migration types suggests a complex of various adaptations (ethological, morphological, and physiological) in the juveniles and the formation of the corresponding phenotypic groups. In literature sources, there is information on the particular features of the behavior and orientation of sockeye salmon underyearlings in the current and their physiological status during the dispersion, obtained both as a result of observations in field and laboratory experiments (Byrne, 1968; Raleigh, 1971; Brannon, 1972; Brett and Glass, 1973; Bodznick, 1978; Hensleigh and Hendry, 1998; Pon et al, 2007; Pavlov et al., 2012, 2013; Zvezdin et al., 2015).

The school of juveniles from spawning grounds located in different parts of the lake and river system in one feeding reservoir requires a specific study. The first steps in this direction should be descriptions of the migratory behavior and phenotypic diversity of juveniles (the progeny of different spawning groups of sockeye salmon) during migrations to the feeding reservoir, which was the goal of this study. 


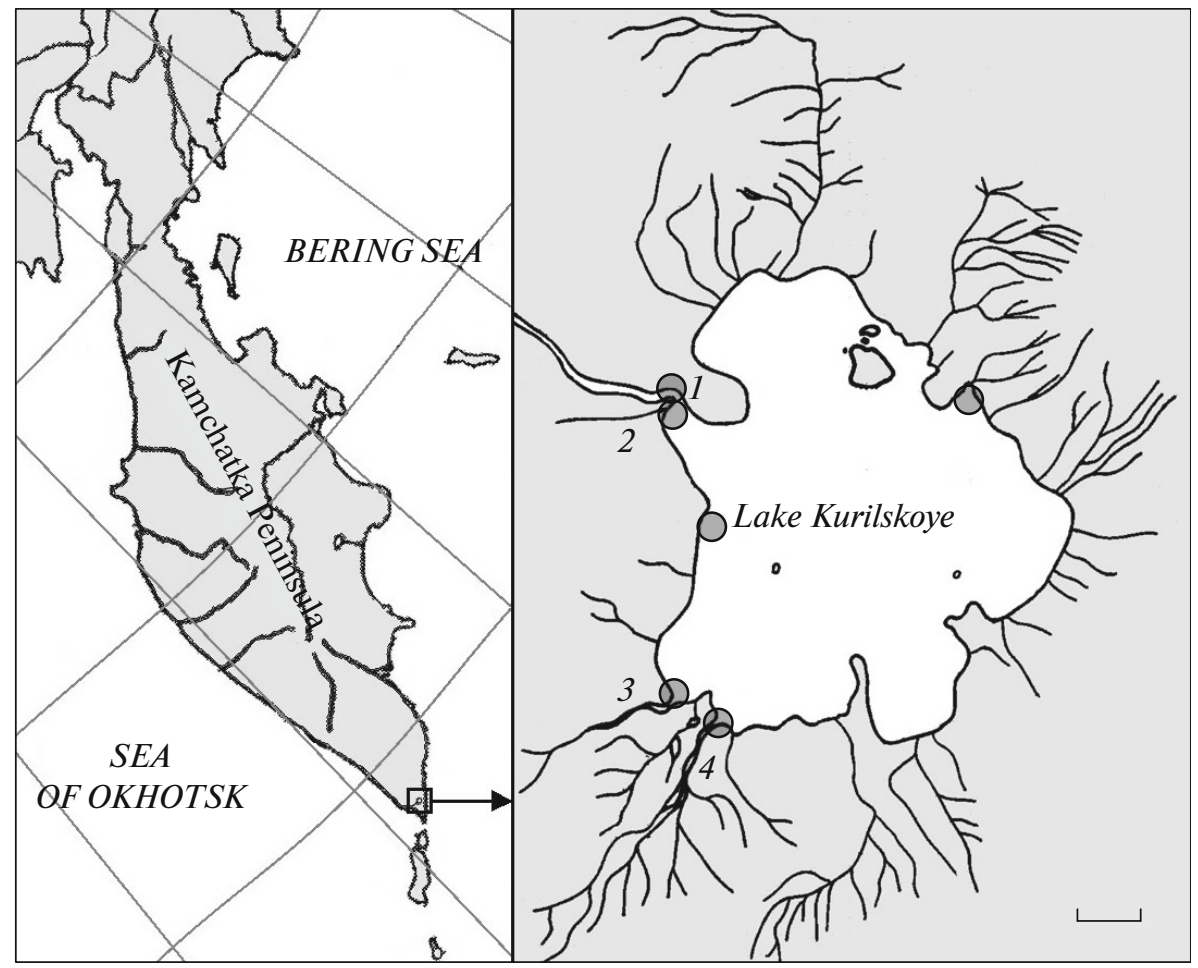

Fig. 1. Schematic map of study area and catching localities (O) for underyearlings of sockeye salmon Oncorhynchus nerka; 1 , source of Ozernaya River; 2, Zolotoi Klyuch stream; 3, Etamynk River; 4, Khakytsin River. Scale: 2 km.

\section{MATERIALS AND METHODS}

Lake Kurilskoye (Ozernaya River Basin) is a large waterbody on the southern Kamchatka Peninsula (Fig. 1): the area of the water surface is $77.1 \mathrm{~km}^{2}$, the volume is $15 \mathrm{~km}^{3}$, the average depth is $195 \mathrm{~m}$, and the maximum depth is $316 \mathrm{~m}$. Four large rivers (the Khakytsin, Etamynk, Vychenkiya, and Kirushutk), several small rivers, and many large and small streams (Zolotoi Klyuch and other nameless tributaries) empty into the lake; the majority of the latter are temporary and exist only in the period of snow melting. Sockeye salmon uses approximately ten lake tributaries for spawning. The Ozernaya River (length $48 \mathrm{~km}$ ), which flows from Lake Kurilskoye, empties into the Sea of Okhotsk. The sockeye salmon spawning grounds are located in the upstream river, over $6 \mathrm{~km}$ from its source, and they comprise approximately $14 \%$ of the area of all spawning grounds (Ostroumov, 1970).

Sockeye salmon underyearlings were caught in the lower reaches of tributaries of Lake Kurilskoye: in the Zolotoi Klyuch stream in 2010-2012, the Khakytsin and Etamynk rivers in 2013; in the upper reaches and at the source of the Ozernaya River; and in the littoral area of the lake in 2010-2013. (Fig. 1). Catches in the Zolotoi Klyuch stream, in the upper reaches of the Ozernaya River, and in the littoral area of the lake were performed regularly, and randomly in the Khakytsin and Etamynk rivers. The juveniles were caught by active and passive fishing gear: conical nets (capron sieve no. 14 , mesh size $0.5 \mathrm{~mm}$, area of entry $0.35 \mathrm{~m}^{2}$, length $2 \mathrm{~m}$ ) and nets with knotless small size mesh netting (cell size $4 \mathrm{~mm}$ ). To capture downstream-migrating juveniles in lake tributaries, a conical net was set in a straight section of the river channel in their lower reaches after fastening it to a rope stretched across the river. In the Ozernaya River, a conical net was set up from a bridge $800 \mathrm{~m}$ below the source of the river. Catches were also taken directly at the source of the river. The exposition of the net was 5-30 min, depending on the velocity of the current, the concentration of ripple-wake suspension, and intensity of migration. Underyearlings caught in the conical net were collected in a plastic glass fixed at the end of the net, which kept them from harm. Juveniles in the near-shore area of the river that were not migrating at that time were caught by targeted netting at particular stations. To capture juveniles in the littoral areas of the lake, a small beach seine (length $10 \mathrm{~m}$, wall height $1.5 \mathrm{~m}$ ) made of knotless mesh netting with a size of $4 \mathrm{~mm}$ ) was used.

Catches were performed both in the twilight-night period (with an illumination of $0.001-100 \mathrm{lux}$ ) and in the daytime (1000-100000 lux). Control catches for confirmation of the night character of migration were performed in the daytime. To determine the daily patterns of migration, downstream-migrating juveniles were caught at intervals of $0.5-1.0 \mathrm{~h}$ in the twilightnight period and $3-4 \mathrm{~h}$ during daylight hours. The 
Table 1. Volume of collected material

\begin{tabular}{|c|c|c|c|c|}
\hline \multirow[b]{2}{*}{ Group } & \multirow[b]{2}{*}{ Year } & \multicolumn{2}{|c|}{ Date } & \multirow{2}{*}{$\begin{array}{l}\text { Fish collected } \\
\text { for biological } \\
\text { analysis, ind. }\end{array}$} \\
\hline & & $\begin{array}{l}\text { catches, } \\
\text { number }\end{array}$ & $\begin{array}{l}\text { caught fish, } \\
\text { individuals }\end{array}$ & \\
\hline \multirow[t]{3}{*}{ Downstream migration in Ozernaya River* } & 2010 & 123 & 653 & 65 \\
\hline & 2011 & 61 & 251 & 158 \\
\hline & 2012 & 28 & 64 & 20 \\
\hline \multirow[t]{3}{*}{ Upstream migration in Ozernaya River } & 2010 & 4 & 232 & 232 \\
\hline & 2011 & 24 & 1401 & 1401 \\
\hline & 2012 & 4 & 185 & 185 \\
\hline \multirow[t]{4}{*}{ Downstream migration in lake tributaries } & 2010 & 24 & 9 & 9 \\
\hline & 2011 & 30 & 0 & 0 \\
\hline & 2012 & 19 & 24 & 24 \\
\hline & 2013 & 4 & 170 & 170 \\
\hline \multirow[t]{3}{*}{ Accumulation at source of Ozernaya River } & 2010 & 2 & 225 & 64 \\
\hline & 2011 & 4 & 282 & 282 \\
\hline & 2012 & 2 & 75 & 75 \\
\hline \multirow[t]{3}{*}{ Juveniles in littoral of lake } & 2010 & 1 & 50 & 50 \\
\hline & 2011 & 12 & 554 & 554 \\
\hline & 2012 & 2 & 60 & 60 \\
\hline
\end{tabular}

* Catching of downstream-migrating juveniles at source of river was performed on July 9, 2011 (five conical nets).

concentration of downstream migrants in the flow calculated by the standard methodology (Pavlov et al., 2015) served as a quantitative measure of the intensity of downstream migration. The volume is shown in Table 1.

In addition to the catches, regular visual observations of the behavior of juvenile sockeye salmon in the Ozernaya River and in the littoral of the lake were performed, accompanied by above-water and underwater photo and video surveys.

During the entire study period, simultaneously with the catches, the temperature (YSI 556-02 temperature sensor of the hydrological probe), water level (stationary graduated pole with an accuracy of $0.5 \mathrm{~cm}$ ), velocity (FlowTracker Handheld-ADV), and illumination (LX1010B lux meter, measurement range 0100000 lux) were measured.

Caught fish were fixed with $10 \%$ formaldehyde. In laboratory conditions, the fork length and body weight were measured, and the composition of the food bolus, the stomach fullness indices (SFI), and the frequency of occurrence of food objects were determined. Analysis of feeding was performed according to (Methodology..., 1974).

The material was statistically processed with standard descriptive statistics in MS Excel 2013 and Statistica 10 software.

\section{RESULTS}

Migration Patterns of Sockeye Salmon Underyearlings from Different Types of Spawning Grounds

The migration of sockeye salmon underyearlings from the spawning grounds located in the tributaries of the lake begins at the end of May or early June, when rivers become free of ice and snow. The duration of migration is short in both large (Khakytsin and Etamynk rivers) and small water courses (Zolotoi Klyuch stream): from 2 weeks to 1 month.

In the Zolotoi Klyuch stream in 2010 and 2012, migration was not as a mass (Fig. 2) and no downstream-migrating sockeye salmon were discovered at all in 2011. In the lower reaches of the Khakytsin and Etamynk rivers in the last third of May 2013, sockeye salmon underyearlings were numerous in the conical net catches: $14-26$ and $10-56$ ind./10 min, respectively. By the middle of June, downstream-migrating fishes were already absent in the catches, but small schools of sockeye salmon appeared that had not been observed earlier in the littoral of the lake near the mouths of rivers. We think that these schools are comprised of juveniles that left the tributaries.

Migration from the lake tributaries occurred only at night. The first migrants appeared in the stream at $<1$ lux illumination. In small water courses (Zolotoi Klyuch stream), migration ceased when illumination decreased to 0.001 lux, and in large water courses 


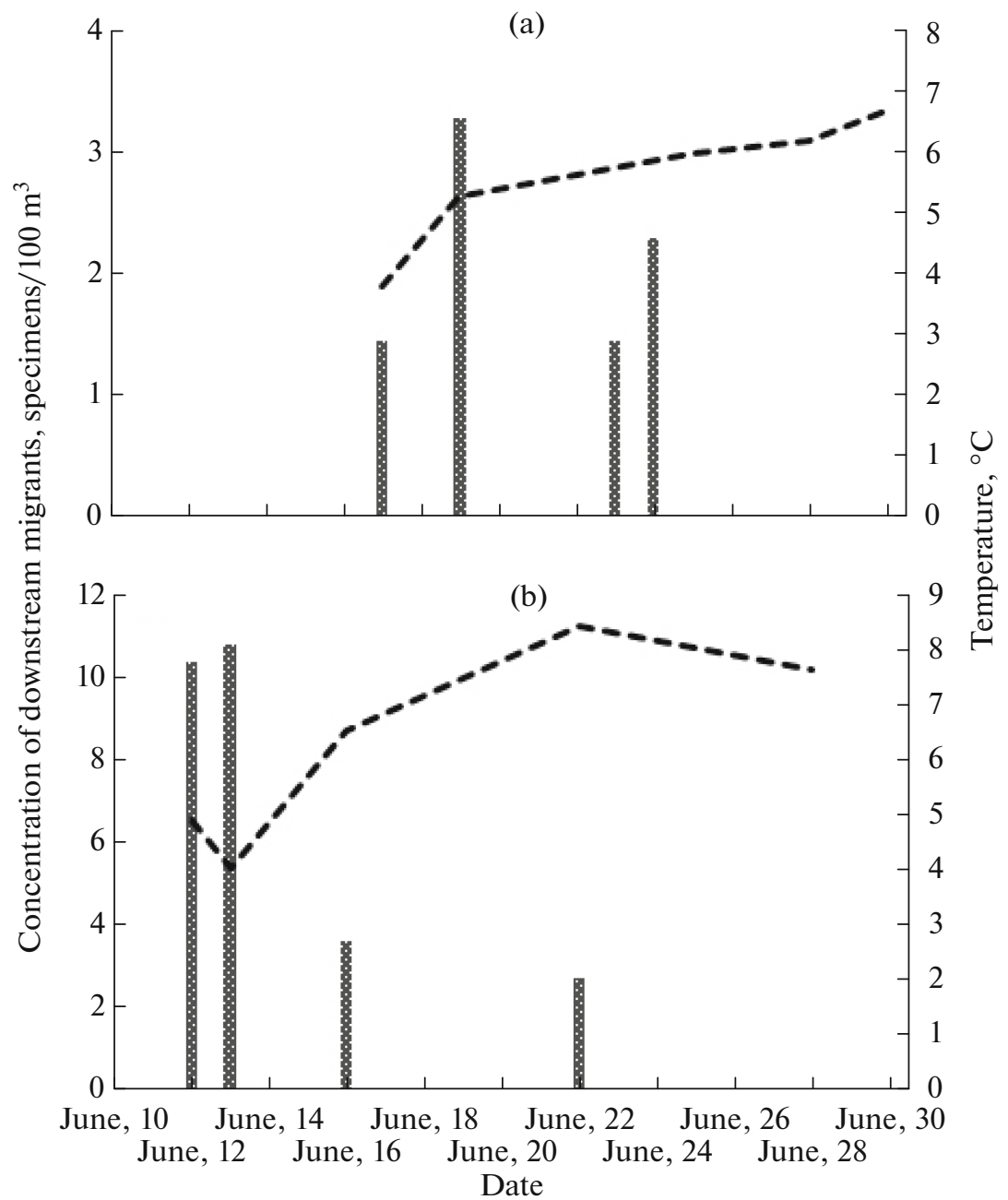

Fig. 2. Intensity of downstream migration of underyearlings of sockeye salmon Oncorhynchus nerka from Zolotoi Klyuch stream (國) and water temperature (---) in June: (a) 2010, (b) 2012.

(Etamynk and Khakytsin rivers) it continued until dawn ( $>1$ lux).

We recorded sockeye salmon underyearlings moving from the spawning grounds of the Ozernaya River, which flows from the lake, in the direction of the lake upstream over the entire period of observation: from the beginning of June to the beginning of October. During migration, juveniles gathered in schools, which moved along the banks of the river, where the flow velocity is minimal $(0.1-0.2 \mathrm{~m} / \mathrm{s})$. The active movement of fish against the current stopped periodically: they went from the main course into reservoirs secondary waterbodies (deep creeks and small deepenings in the coastline, covered by vegetation hanging over water, and streams abundantly overgrown with macrophytes). After leaving the mainstream, schools dispersed and fishes were positioned arbitrarily with respect to each other. In accessory waterbodies, sockeye salmon juveniles fed intensely. Fishes performed directed thrusts into the water column and towards the surface, accompanied by seizing motions. Digestive tracts in juveniles from the accessory waterbodies were filled with food. During the migration, the juveniles did not display foraging behavior.

Upstream migration (Fig. 3) occurred during the day (Figs. 3a, 3b, 3e): it began at dawn with an illumination of 100 lux and ended after sunset at $0.1-1.0$ lux. At twilight, sockeye salmon underyearlings departed from the mainstream into the accessory waterbodies or distributed themselves in the mainstream near the water's edge in places where water-flooded vegetation is present (Fig. 3d). At night (0.001-0.010 lux), fishes were not active: they lay separately on the bottom or in groups without reacting to weak stimuli (dim scattered light from a flashlight, smooth touching by the net). Exposure to bright light frightened the underyearlings, which ascended abruptly from the bottom into the water column and performed chaotic thrusts in different directions. After 1-2 min, some of the fishes hid in the vegetation or flooded roots of plants; the rest 


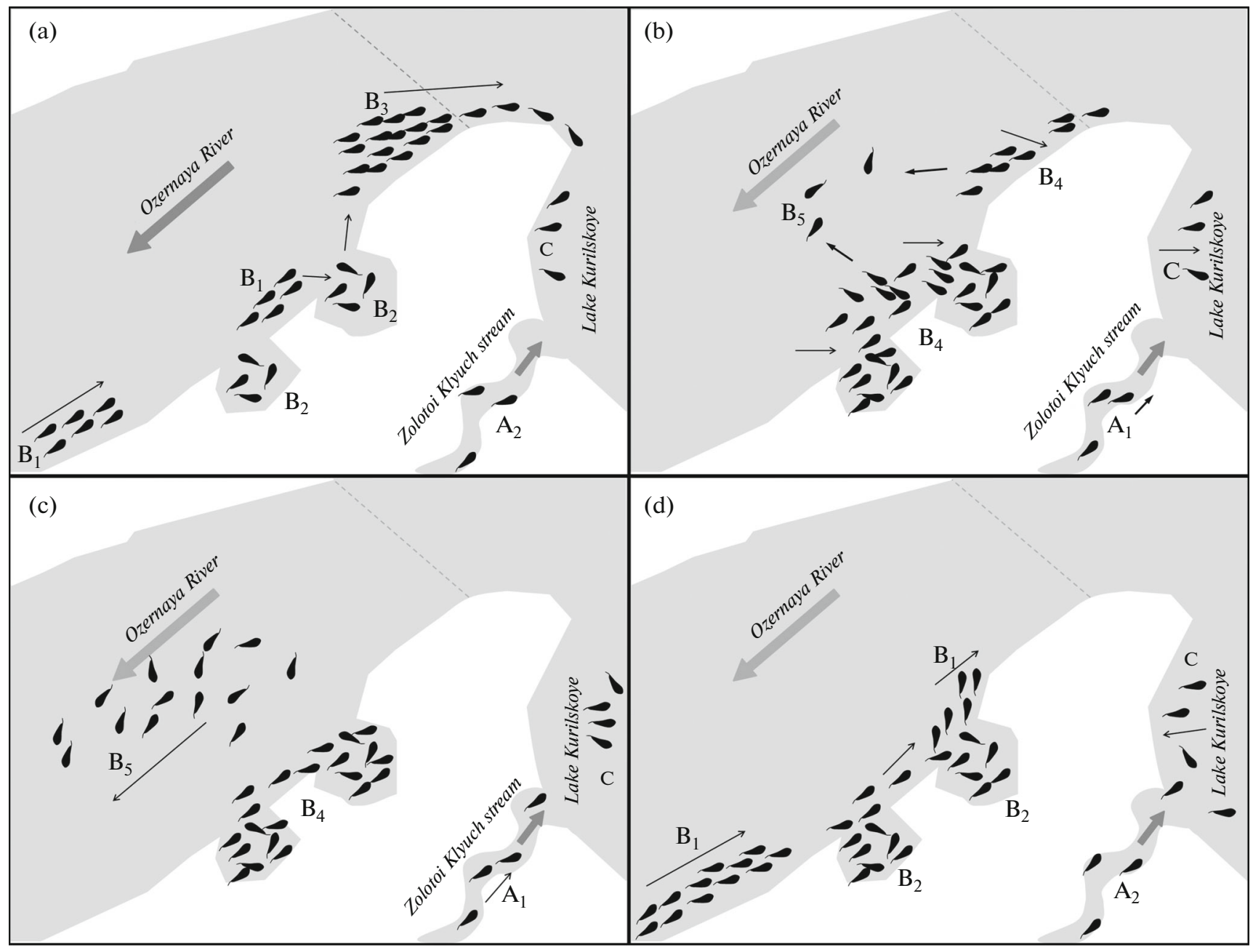

Fig. 3. Distribution of juvenile sockeye salmon Oncorhynchus nerka in Ozernaya River, Zolotoi Klyuch stream, and in littoral of Lake Kurilskoye under different illumination conditions: (a) day, (b) twilight, (c) night, (d) dawn. $\mathrm{A}_{1}$, migrants from lake tributaries; $A_{2}$, underyearlings in shelters and coastal areas of lake tributaries; $B_{1}$, migrants against current; $B_{2}$, underyearlings in accessory system of Ozernaya River; $\mathrm{B}_{3}$, school at source of Ozernaya River; $\mathrm{B}_{4}$, underyearlings in shelters and coastal area of Ozernaya River; $\mathrm{B}_{5}$, downstream migrants in Ozernaya River; C, juveniles in littoral of lake; $(\longrightarrow)$, direction of current; $(\rightarrow)$, direction of fish movement.

departed into the mainstream of the river and entered the transit flow.

The reverse process, downstream migration of some underyearlings, was accompanied by mass upstream migration (Figs. 3b, 3c). The proportion of such migrants is insignificant with respect to the fish ascending into the lake. In 2010 and 2011, sockeye salmon underyearlings occurred in conical net catches from the onset of observations (June 12 and 14, respectively). In both years, downstream migrants mostly occurred on the right bank of the river, while very little or no migrants occurred on the left bank. The highest concentrations of downstream-migrating sockeye salmon underyearlings in 2010 were recorded in the period from June 30 to July 7 (Fig. 4a): migration peaks were noted consecutively in the midstream, on the left bank, and on the right bank of the river. In
2011, the highest concentrations of downstreammigrating fishes were recorded on June 18 and 3 July (Fig. 4b). No downstream-migrating underyearlings were observed on the left bank at all. The differences in migration intensity on the left and right banks and in the midstream are caused by particular features of the riverbed structure: the left bank is an extensive shallow water area with a decelerated current; the right bank is washed by the stream, and the flow rate along it is insignificantly smaller than in the midstream. The number of underyearlings in conical net catches increased when there was a strong ESE wind, which generated a strong downward current. From the left bank, where there are numerous waterbodies secondary waterbodies in which sockeye salmon underyearlings gather, they are driven away into the mainstream and picked up by the transit flow. 

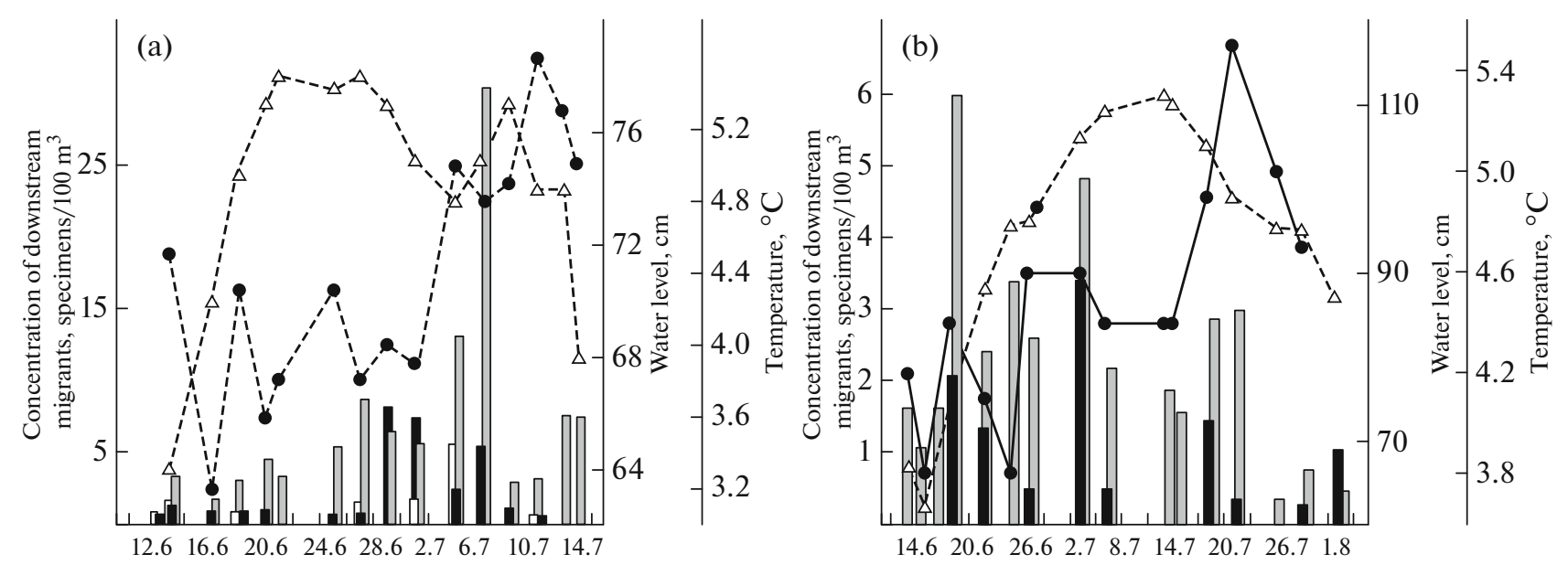

Date

Fig. 4. Downstream migration dynamics for underyearlings of sockeye salmon Oncorhynchus nerka near left $(\square)$ and right $(\square)$ banks and in midstream ( $\square$ ) of river and temperature (--) and water level fluctuations (- $\triangle-)$ in Ozernaya River in June-July: (a) 2010, (b) 2011 .

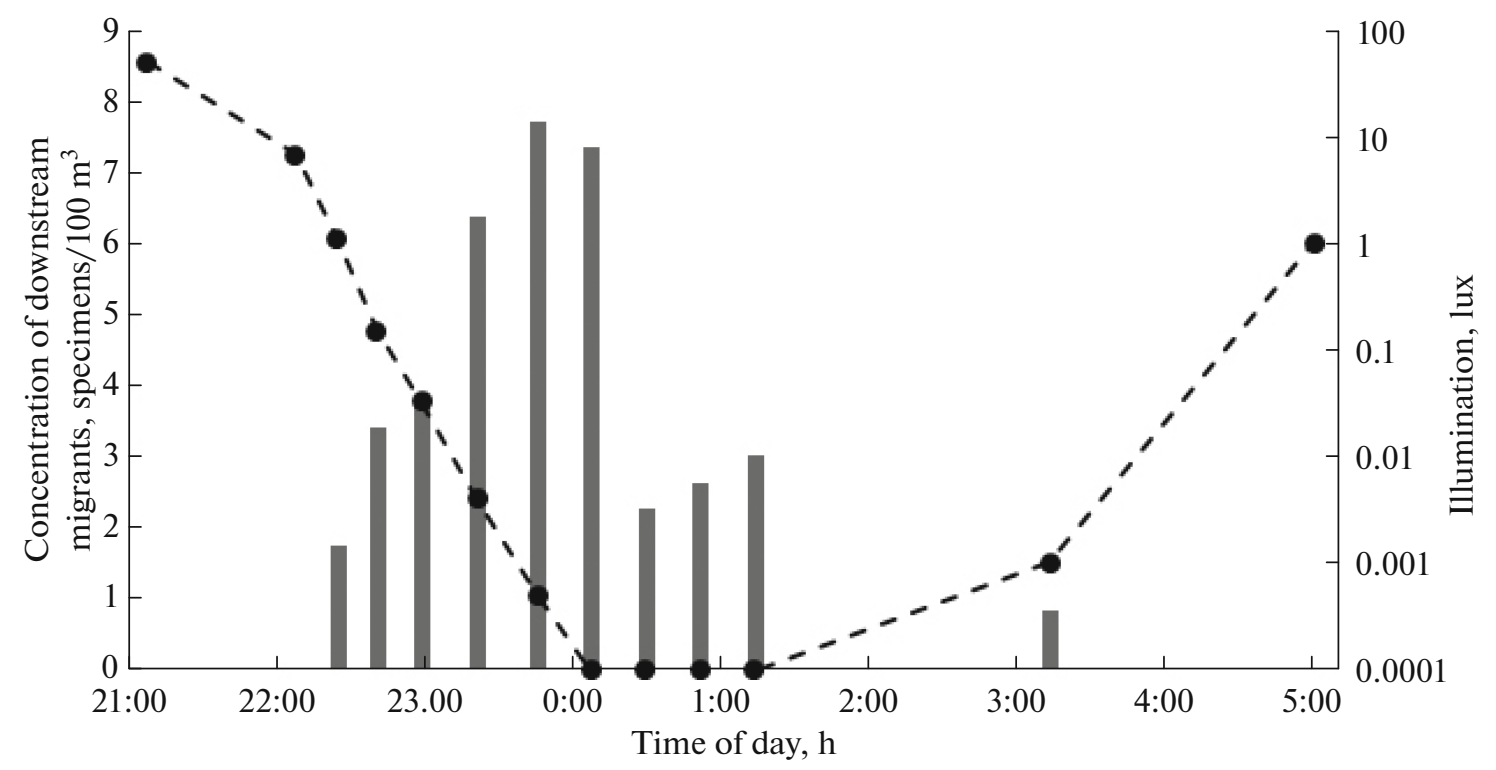

Fig. 5. Intensity of downstream migration of underyearlings of sockeye salmon Oncorhynchus nerka ( ) in Ozernaya River depending on illumination (-๑-), July 12-13, 2010.

Migration of underyearlings downstream the Ozernaya River, similar to that from the lake tributaries, occurred at night: it began with a reduction in illumination to 1 lux and ended with the dawn (Fig. 5).

It should be noted that no underyearlings leave the lake for the river. In the conical net set directly at the source of the river, no individuals were caught, whereas downstream-migrating fishes were present in the downstream catches. Sockeye salmon juveniles spend some time at the source of the Ozernaya River before entering the lake, concentrating in the daytime in the eddy zone near the left bank. Underyearlings coming from below areas join into a single large school
(Fig. 3a), which is constantly replenished with small schools approaching from below. From its head end, one to three individuals consecutively separate and enter the lake. Their relocation occurs at the very edge of the water, where the flow rate is minimal. In order to enter the lake, underyearlings perform a series of consecutive thrusts, which alternate with short-term resting in the hydraulic shadow of stones and other objects on the river bottom. After dark (0.1 lux), the school disbands at the source of the river: underyearlings move into the nearest shelters: secondary channels, creeks, scours in the banks (Fig. 3b). 
In the lake spawning grounds, sockeye salmon spend the first weeks after emerging from the ground in coastal waters where the depth does not exceed $1 \mathrm{~m}$. In the littoral of the lake, juveniles are not affected by the transit flow like in rivers. Only under unfavorable meteorological conditions (strong wind and waves) juveniles move farther from the coast or hide among stones. In summer, underyearlings of lake origin mix with those that migrated into the lake from the tributaries and from the Ozernaya River. Density of juvenile sockeye salmon in the littoral of the lake gradually increases from the end of May to August: from single fishes to thousands of individuals per $1 \mathrm{~m}^{2}$. Mass movement to the pelagic zone begins in August. Juveniles gradually move farther from the coasts; at the same time, they avoid the surface layer and remain in the water column. In the period when they inhabit the littoral area of the lake, sockeye salmon underyearlings demonstrate typical school behavior. Frequently, sockeye salmon schools are mixed with schools of threespined sticklebacks Gasterosteus aculeatus, juveniles of which also spend the first weeks of life in the littoral area of the lake. Sockeye salmon feed intensely for the entire feeding period in the littoral area of the lake.

Thus, the different types of migratory behavior demonstrated by sockeye salmon during migration from spawning grounds in the Lake Kurilskoye Basin make it possible to define three basic phenotypic groups, which in turn have a complex internal structure and are represented by different spatiotemporal groups: A, underyearlings from the tributaries of the lake: at night they migrate downstream $\left(\mathrm{A}_{1}\right)$, by day they stay in various shelters in the rivers that flow into Lake Kurilskoye $\left(\mathrm{A}_{2}\right)$; $\mathrm{B}$, underyearlings in the river flowing from the lake: by day some of the individuals moves upward against the current $\left(B_{1}\right)$, while others stay in the secondary waterbodies $\left(\mathrm{B}_{2}\right)$; before entering the lake, underyearlings coming from areas located downstream gather into a school at the source of the river $\left(B_{3}\right)$; at night, the majority of underyearlings are in a resting state in a closed coastal area and in the secondary waterbodies $\left(\mathrm{B}_{4}\right)$, and an insignificant number migrate downstream $\left(\mathrm{B}_{5}\right)$; $\mathrm{C}$, underyearlings in the littoral of the lake, originally represented by generative lake individuals. The last one form mixed schools with migrants from the tributaries and Ozernaya River flowing from the lake. They stay in the shallow water near the shore, demonstrating typical school behavior, and move into deeper areas of the lake at night. In summer, they move to the pelagic zone, closer to the main feeding areas.

\section{Size Composition of Sockeye Salmon Underyearlings during Migration to the Feeding Reservoir}

Representatives of different groups vary in linear dimensions (Table 2): individuals that migrate downstream in the tributaries of the lake $\left(\mathrm{A}_{1}\right)$ and in the Ozernaya River $\left(\mathrm{B}_{5}\right)$ are significantly smaller $(p<$ $0.05)$ than fishes that move against the current $\left(B_{1}\right)$. Underyearlings from the littoral of the lake $(C)$ and those in the school at the source of the river $\left(B_{3}\right)$ are larger than the migrants that move downstream $\left(\mathrm{B}_{5}\right)$, but differences are statistically insignificant. Migrants moving upstream $\left(B_{1}\right)$ do not significantly differ in size from underyearlings in the littoral of the lake (C) and in school at the source of the river $\left(B_{3}\right)$.

\section{Feeding Specifics of Sockeye Salmon Underyearlings}

The stomach fullness of juveniles from different groups differs considerably. The largest SFI values were observed in fish from the school at the source of the river $\left(\mathrm{B}_{3}\right)$ : the average was $53.9 \%$ oo, and the maximum was $520.1 \% 00$ (64 individuals); however, $25 \%$ of these fish did not feed. Underyearlings moving downstream $\left(\mathrm{B}_{5}\right)$ had the smallest SFI: 9.8 and $31.3 \%$ oo,

Table 2. Length $(F L)$ of sockeye salmon underyearlings Oncorhynchus nerka from various groups

\begin{tabular}{|c|c|c|c|c|c|c|}
\hline \multirow{2}{*}{ Group } & \multirow{2}{*}{$n$, ind. } & \multicolumn{3}{|c|}{$F L, \mathrm{~mm}$} & \multirow{2}{*}{$\sigma$} & \multirow{2}{*}{$\mathrm{CV}$} \\
\hline & & $M$ & $\min$ & $\max$ & & \\
\hline & \multicolumn{6}{|c|}{ June $21-22,2010$} \\
\hline Migrants against current $\left(\mathrm{B}_{1}\right)$ & 51 & 31.2 & 28.8 & 36.0 & 1.35 & 4.33 \\
\hline School at source of Ozernaya River $\left(B_{3}\right)$ & 50 & 30.6 & 28.0 & 33.0 & 0.92 & 3.01 \\
\hline \multirow{2}{*}{ Migrants downstream Ozernaya River $\left(B_{5}\right)$} & 43 & 30.3 & 22.9 & 32.2 & 1.59 & 5.24 \\
\hline & \multicolumn{6}{|c|}{ June $17-19,2012$} \\
\hline Migrants from lake tributaries $\left(\mathrm{A}_{1}\right)$ & 14 & 27.7 & 24.0 & 31.0 & 2.22 & 8.04 \\
\hline Migrants against current $\left(\mathrm{B}_{1}\right)$ & 64 & 29.0 & 25.0 & 39.5 & 2.76 & 9.53 \\
\hline Migrants downstream Ozernaya River $\left(\mathrm{B}_{5}\right)$ & 20 & 27.2 & 24.5 & 29.0 & 1.28 & 4.71 \\
\hline Juveniles in littoral of lake (C) & 36 & 28.0 & 26.0 & 36.5 & 1.88 & 6.71 \\
\hline
\end{tabular}

$n$, size of dataset, individuals; $M$, average length; min, max, range of variation; $\sigma$, standard deviation; $\mathrm{CV}$, coefficient of variation. 

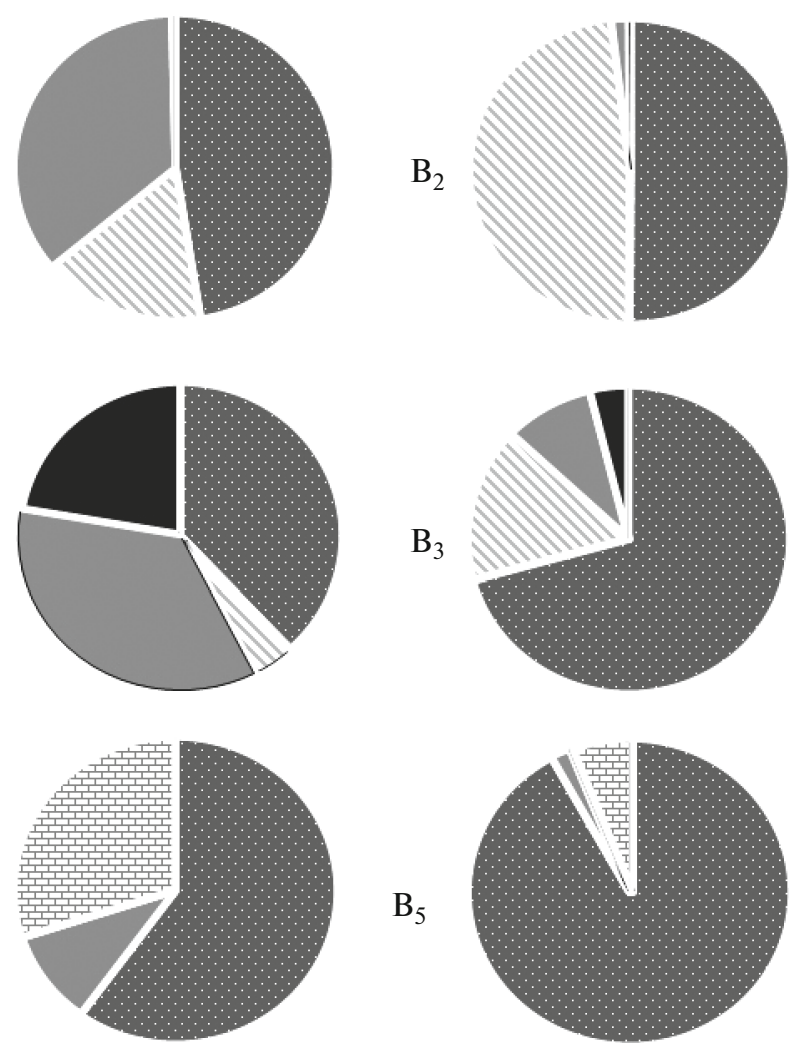

Fig. 6. Significance of individual groups of food objects in diet of sockeye salmon underyearlings Oncorhynchus nerka of different spatiotemporal groups (left, in \% of total food mass; right, in \% of total number of food objects in food bolus): ( $\square)$, larvae and pupae of amphibiotic insects; $(\square)$, planktonic crustaceans; ( $\square$ ), imagoes of amphibiotic insects; ( $\square)$, larvae and imagoes of air insects and terrestrial invertebrates; $(由)$, nonfood objects; group names are listed in Fig. 3.

respectively (65 individuals), and the part of fishes with empty stomachs was $88 \%$. Among fishes from secondary waterbodies, the part of individuals with empty stomachs was minimal $(9 \%)$ in the daytime $\left(\mathrm{B}_{2}\right)$, the average SFI was $38.6 \%$, and maximum was $288.2 \% 00$ (33 individuals).

The main feeding objects of juveniles of the studied groups $\left(\mathrm{B}_{2}, \mathrm{~B}_{3}, \mathrm{~B}_{5}\right)$ were the larvae of amphibiotic insects, mainly Chironomidae (small larvae of ages III) and planktonic crustaceans Copepoda and Cladocera (Fig. 6). The latter are carried in abundance from the lake to the Ozernaya River. The composition of food bolus in the individuals from different groups differed considerably by the frequency of occurrence of specific groups of food objects (Fig. 7). Larvae and pupae of amphibiotic insects (predominantly Chironomidae) and aquatic invertebrates (Copepoda and Cladocera) were recorded more frequently in the stomachs of underyearlings from the secondary waterbodies secondary waterbodies of the Ozernaya River $\left(\mathrm{B}_{2}\right)$. Imago of air and amphibiotic insects and terres-

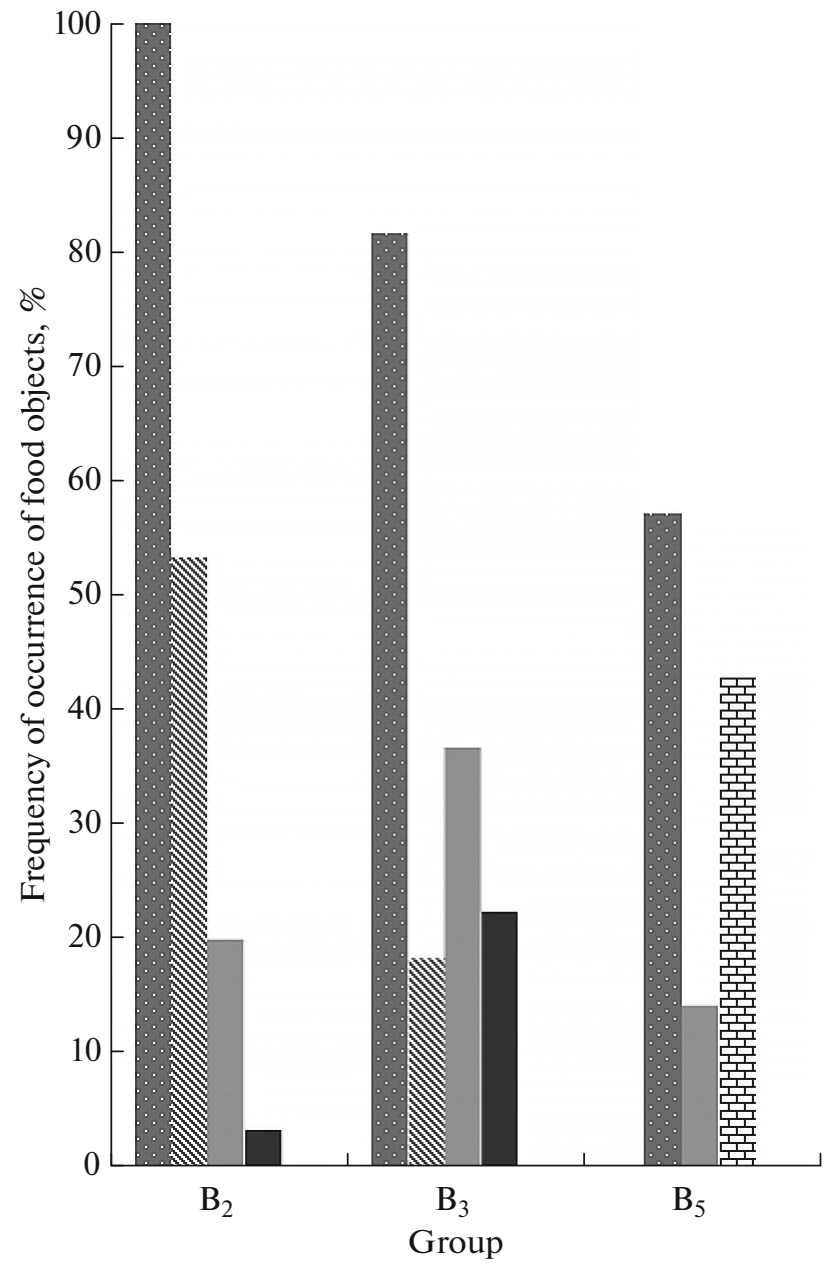

Fig. 7. Frequency of occurrence of individual food objects in diet of sockeye salmon underyearlings Oncorhynchus nerka of different spatiotemporal groups; names are listed in Fig. 3 and Fig. 6.

trial invertebrates predominated in the food of juveniles from the school at the source of the river $\left(B_{3}\right)$. A high frequency of occurrence of nonfood objects (plant particles, bird down hair, etc.) in the underyearlings that migrated downstream $\left(B_{5}\right)$ is notable, whereas similar objects were not found in the stomachs of fishes from the other groups.

Qualitative analysis of feeding of sockeye salmon juveniles from the lake tributaries $\left(\mathrm{A}_{1}\right)$ revealed a number of substantial differences: among fishes from the Etamynk and Khakytsin rivers, there were no individuals with empty digestive tracts. In the food boluses of underyearlings from the Etamynk River, planktonic crustaceans (presumably those carried down from Lake Etamynk, the source of the river of the same name) were predominant. In the Khakytsin River, juveniles fed exclusively on Chironomidae larvae. In the Zolotoi Klyuch stream, the stomachs of underyearlings were empty or contained remainders of small 
Table 3. Phenotypic diversity of underyearlings of sockeye salmon Oncorhynchus nerka in accordance with location of spawning grounds and types of migration

\begin{tabular}{|c|c|c|c|c|}
\hline \multirow{2}{*}{ Type of behavior } & \multirow{2}{*}{ Time of day } & \multicolumn{3}{|c|}{ Location of spawning ground } \\
\hline & & Lake tributaries & Ozernaya River & lake \\
\hline Downstream migration & Night & $\mathrm{A}_{1}$ & $\mathrm{~B}_{5}$ & - \\
\hline Migration against current & Day & - & $\mathrm{B}_{1}$ & - \\
\hline \multirow[t]{2}{*}{ Stalling or absence of active mass relocation } & Night & - & $\mathrm{B}_{4}$ & $\mathrm{C}$ \\
\hline & Day & $\mathrm{A}_{2}$ & $\mathrm{~B}_{2}, \mathrm{~B}_{3}$ & - \\
\hline Nomadic migration & Same & - & - & $\mathrm{C}$ \\
\hline
\end{tabular}

$\mathrm{A}_{1}$, migrants from lake tributaries; $\mathrm{A}_{2}$, underyearlings in shelters and coastal areas of lake tributaries; $\mathrm{B}_{1}$, migrants against current; $\mathrm{B}_{2}$ underyearlings in accessory system of Ozernaya River; $\mathrm{B}_{3}$, school at source of Ozernaya River; $\mathrm{B}_{4}$, underyearlings in shelters and coastal area of Ozernaya River; $B_{5}$, migrants downstream of Ozernaya River; $C$, juveniles in littoral of lake.

Chironomidae larvae in the distal section of the gastrointestinal tract.

Thus, the revealed differences in the particular features of the behavior, length of individuals, and feeding for sockeye salmon underyearlings from spawning grounds in different locations indicate a high degree of phenotypic differentiation within a single population. During the period of migration to the main feeding area (pelagic zone of the lake), sockeye salmon juveniles form several spatiotemporal groups (Table 3 ).

The phenotypic groups that correspond to the types of spawning grounds exist only during the period of migration from the spawning grounds. With transition of sockeye salmon to the pelagic mode of life in the lake, they unite and transform into the unified phenotypic group of pelagic juveniles.

\section{DISCUSSION}

Different arrangements of sockeye salmon spawning grounds with respect to the feeding reservoir and the diverse conditions in them led to the formation of a set of adaptations essential to reach the feeding reservoir, each of which is achieved in juveniles as a particular form of migratory behavior depending on origin. The phenotypic diversity of juveniles is determined by the complex population structure of Ozernaya River sockeye salmon, represented by several ecological forms whose genetic variability is reflected in the heterogeneity of groups of individuals from different spawning periods in the Ozernaya River (Pil'ganchuk et al., 2010; Pil'ganchuk, 2014). A high level of homing and spatiotemporal dissociation of spawning groups of sockeye salmon (Hartman and Raleigh, 1964; Hendry et al., 1995; Varnavskaya, 2006; Khrustaleva, 2007; Pil'ganchuk, 2014) resulted in their genetic differentiation and mainly governed the heritability of the type of migratory behavior in the period of distribution of juveniles from spawning places (Brannon, 1972).

The formation of the corresponding phenotypic groups of juveniles in their first year of life occurs in accordance with genetic differentiation, which was fixed as a result of the three-dimensional dissociation of spawning groups: river (from the tributaries and the effluent river) and lake. Studies of the migration of sockeye salmon underyearlings from spawning grounds demonstrated a more complex nature of intrapopulation differentiation during this period of this species' life cycle. Within the phenotypic groups corresponding to a specific type of spawning grounds, a number of spatiotemporal groups have been revealed that are very labile and capable of transforming into one another, uniting and dividing in a short period of time. To reach the feeding reservoir, sockeye salmon underyearlings from river spawning grounds carry out migrations of two types: downstream (in the tributaries of the lake) and upstream against the current (in Ozernaya River).

Migration from the lake tributaries is downstream and is accomplished via the transport force of the flow. According to our data, migration from tributaries begins no earlier than mid-May, when rivers are free of snow and the water warms up. For example, Krokhin and Krogius (1937) recorded the first free-swimming sockeye salmon juveniles near the mouth of the Etamynk River on May 18. These young fishes probably were precisely of river origin. Our observations in late May-early June demonstrated that at that time a massive movement of sockeye salmon underyearlings occurs.

The duration of migration from the tributaries is short. In the Etamynk and Khakytsin rivers in 2013, there were already no downstream-migrating sockeye salmon in mid-June; a sharp increase in water level caused by intense melting of snow contributed to this phenomenon. Movement of sockeye salmon from the Zolotoi Klyuch stream ends in the last third of June. Apparently, the statement on the duration of the exit of hatchlings from the soil in connection with the extension of spawning (Krokhin and Krogius, 1937; Egorova, 1970; Bugaev, 1995) is fully valid only for relatively large waterbodies. In small water courses, such as the Zolotoi Klyuch stream, the movement of pro- 
ducers does not last long (from one day to a week) and the number of producers is small. Furthermore, pressure from large predators (bears) on the producers of sockeye salmon is great in small water courses. When low numbers of producers enter in a water course, their death rate from predators can reach $100 \%$. The low number of downstream-migrating fishes in the Zolotoi Klyuch stream is, apparently, a consequence of spawning of a small number of producers, short duration of spawning, and a high degree of death from predators in this stream. For example, in 2011, the absence of downstream-migrating sockeye salmon underyearlings in this stream could have resulted from the death of prespawning producers entering the stream. According to a communication from KamchatNIRO employees, in 2010, no more than 150 sockeye salmon individuals entered the stream, which were caught by the bears over a single night.

Migration into the lake from the spawning grounds of the Ozernaya River is directed against the current. This type of migration has significant energy costs. The underyearlings' own energy reserves are small and have to be constantly replenished. Therefore, juveniles feed intensely during the migration. During the migration into the lake, the juveniles are provided with a high-calorie food: planktonic crustaceans carried off from the lake (Akulin, 1968). Analysis of the feeding of sockeye underyearlings in Ozernaya River revealed that these food objects predominate in the food bolus. The availability of such food not only compensates the energy costs of juvenile fish overcoming the current but also creates preconditions for some individuals staying in the waterbodies secondary waterbodies. The latter is evidenced by a significant variability in the size composition of sockeye salmon underyearlings in the Ozernaya river cease with nightfall.

Obviously, the frequent change in foraging and migratory behavior, which occurs several times during the daytime, is an adaptation of protection from predators (fishes and birds) to which sockeye salmon juveniles are easily available at high illumination. In addition to the segregation of the two behavioral forms, each is associated with specific adaptations for the most effective defense: underyearlings gather in schools during the migration and move to special feeding stations protected from predator attacks from the water and air. In the daytime, the feeding of sockeye salmon juveniles is the most efficient, since the visual analyzer is the major one for the search and seizure of food objects for this species, just like for other salmon. The role of sight is especially great when feeding on small objects suspended in the water column: planktonic crustaceans and chironomid larvae.

In addition to mass migration against the current toward the lake, we found the opposite process in a number of sockeye salmon underyearlings in the Ozernaya River: downstream migration. A number of patterns during migration and the morphological characteristics of fishes (Kirillova and Pavlov, 2011; Pavlov et al., 2012) prevent downstream migration of sockeye salmon underyearlings in the river flowing from the lake from being considered a stochastic phenomenon. Downstream migration, along with mass migration against the current, is also known for sockeye salmon underyearlings that have recently emerged from the ground in rivers of North America (Hartman et al., 1967; McCart, 1967; Brannon, 1972). Downstream migration of sockeye salmon underyearlings in the river flowing from the feeding reservoir can be both a manifestation of innate behavioral reaction (Brannon, 1972; Kirillova and Pavlov, 2011; Pavlov et al., 2012) for dispersal from river spawning grounds and distribution in the coastal zones and a result of the influence of external factors (predator attacks, movement of bears in shallow water, etc.). The downstream migration of Ozernovskaya sockeye salmon is characterized by its small length: entry to the sea in the first year of life has not been recorded (Pavlov et al., 2015). Apparently, soon after distribution in the coastal area of the river, underyearlings begin migration into the feeding reservoir.

Seasonal variation in migration intensity is associated with the redistribution of juveniles in the coastal area as a result of seasonal variations in the water level and direction of wind-driven currents. Differences in migration intensity in 2010 and 2011 are the result of interannual variations in the water content of the river, which determines the presence and accessibility of shelter. In 2010, characterized by a low level of water (Fig. 4a), many bays and creeks in which the juveniles resided dried out by the beginning of July. A shortage of temporary habitats led to an increased number of underyearlings that entered the current in the nighttime. In 2011, which was a high-water year (Fig. 4b), downstream sockeye salmon migrants were scarce when, as a result of a protracted spring flood, temporary habitats suitable for residence and feeding were accessible for the entire summer. We have studied the dependence of migration intensity on the water content of the river in the period of distribution of juveniles of coho salmon Oncorhynchus kisutch and Kamchatkan rainbow trout Parasalmo mykiss in the first year of life (Pavlov et al., 2010). It is possible that some of the downstream migrants are composed of individuals that entered the current as a result of attacks from predators (large juveniles of Dolly Varden Salvelinus malma and coho salmon) or that were driven from shelters by bears moving along the coast. According to our data, sockeye salmon underyearlings are a major food object of large juveniles of Dolly Varden and coho salmon: in the Ozernaya River, more than 50\% of coho salmon juveniles and $30 \%$ of Dolly Varden juveniles had sockeye salmon underyearlings in the food bolus composition. Moreover, the most intense consumption of underyearlings occurred during evening hours, in the period of rapid reduction in illumination, when their schools migrating upstream were 
disbanding and they were passing from the main current into the waterbodies of accessory systems and into the shelters. The association of downstream migration of early juveniles to the dark time of day is a universal adaptation for protection from predators (Pavlov, 1979).

The study of rheoreaction of the sockeye salmon underyearlings in Ozernaya River that migrated upstream revealed that the members of this group maintain a positive type of rheoreaction only for lake water (Pavlov et al., 2013). The smell of water flowing from the lake serves as a basic orientation cue for movement of underyearlings (Brannon, 1972; Zvezdin et al., 2015). Apparently, manifestation of a positive rheoreaction is genetically fixed, but the realization of an innate behavioral program occurs under specific conditions. An essential condition for manifestation of positive rheoreaction and migration against the current is the odor of a feeding reservoir in the water. This olfactory orientation cue not only helps underyearlings to reach the feeding lake but also possibly prevents their entry into lake tributaries and river effluent.

The presence of planktonic crustaceans in the water, which is the main food object of sockeye salmon during the freshwater period of the life cycle, is a leading, but not the only component of the olfactory attractiveness of the lake. For example, under experimental conditions, in juveniles from the Ozernaya River brought into the Zolotoi Klyuch stream, the positive rheoreaction changed to negative even when they were additionally fed planktonic crustaceans (Pavlov et al., 2013; Zvezdin et al., 2015). In the water of tributaries, there is no odor of the feeding lake to which sockeye salmon juveniles demonstrate a preference by (Bodznick, 1978; Pavlov et al., 2013; Zvezdin et al., 2015); this stimulates the formation of a negative rheoreaction. It is also possible that the presence of significant concentrations of predator kairomones, primarily Dolly Varden juveniles, in the water of tributaries is an important component in determining the quick completion of downstream migration from tributaries.

The formation of the school school at the source of the river apparently occurs due to the impossibility of a majority of individuals to immediately overcome the current, the velocity of which is considerably higher at the source of the river and exceeds the critical current velocity for sockeye salmon juveniles throughout the entire width of the riverbed, with the exception of a small section near the coast. Entry into the lake is possible only near the very edge of the water along the left bank, where the current velocity is lower. The school of sockeye salmon underyearlings at the source of the river is a special spatiotemporal group for which unification of sockeye salmon of lake origin precedes that of river sockeye salmon.

In the littoral of the lake, far from the junctions of lake tributaries, sockeye underyearlings are apparently initially represented only by lake generative individuals. They subsequently unite with underyearlings of river origin that enter the lake. In the littoral, sockeye salmon frequently school together with threespined stickleback Gasterosteus aculeatus. This phenomenon is well known for sockeye salmon underyearlings (Brannon, 1972) and differently aged juveniles of other fish species (Pavlov and Kasumyan, 2000).

In the lake, schools of sockeye salmon underyearlings mostly keep to open areas with stony or sandy soil, avoiding bays overgrown with macrophytes and sections of coast with overhanging vegetation, which are typical habitats of two- and three-year-old coho salmon. As underyearlings grow, they nomadically migrate farther from the coast and by the end of summer they are almost completely absent in the littoral of the lake, where mass spawning of sockeye salmon takes place at this time and Dolly Varden individuals of varying ages accumulate to feed on the eggs.

The diverse reproductive conditions of sockeye salmon within the limits of one water basin and the associated diversity of feeding migrations of underyearlings resulted in the formation of a number of morphophysiological adaptations. Makkart and Pon (McCart, 1967; Pon et al., 2007) noted a larger size of sockeye salmon underyearlings undertaking upstream feeding migrations. Obviously, fish actively migrating against the current need greater muscle mass and significant energy reserves. Earlier, we showed (Pavlov et al., 2012) that underyearlings from different spatial groups vary in the content of individual lipid classes. In the bodies of upstream migrants, the content of triacylglycerins, which are a basic energy source, is higher than in downstream migrants, just like in the fish from accumulation at the source of the Ozernaya River.

Obviously, the SFI values from different lake tributaries depend on the feeding conditions and determine the time and intensity of migration. The smallest SFI values were those of downstream migrants into the Zolotoi Klyuch stream, migration from which occurs over very short time periods. A low SFI is apparently caused by the absence of accessible food objects or by conditions for catching them. In large water courses (Khakytsin and Etamynk rivers), all underyearlings had full digestive tracts. In the river flowing from the lake, intense feeding is a necessary condition that ensures the fish reach the feeding reservoir.

\section{CONCLUSIONS}

The diverse reproduction locations of sockeye salmon in the Lake Kurilskoye Basin predetermined several forms of migrations into the feeding reservoir. It is well known that, in the majority of fish species, passive downstream migrations, which are the least energy-consuming, play the key role in juveniles reaching the feeding places. However, due to the 
arrangement of a substantial portion of sockeye salmon spawning grounds in the river that flows from the feeding lake, active migration of juveniles against the current is of great significance. Various environmental conditions and need for different forms of migratory behavior to ensure fish reach the feeding reservoir have resulted in a number of intraspecific phenotypic groups in sockeye salmon underyearlings that correspond to the types of spawning grounds. Phenotypic groups, in turn, have a complex structure, as labile spatial and temporal groups are formed within them. A specific trait of the phenotypic polymorphism revealed in the population of sockeye salmon is its temporal nature. This polymorphism does not lead to the formation of various finite intraspecific forms or phenotypes of spawners (anadromous and resident fish). The trajectories of ontogenetic development of different groups of sockeye salmon underyearlings that reach the feeding reservoir converge as the transition to habitation of first the coastal area and then to the pelagic zone of the lake occurs. The unification of initially qualitatively differing juveniles into a combined pool occurs during the first months of life of juveniles, long before their smoltification and migration into the sea. The uniqueness of this phenomenon deserves not only field, but also experimental studies in the future.

\section{ACKNOWLEDGMENTS}

We are grateful to the administration of KamchatNIRO and the Kronotsky State Natural Biosphere Reserve for the opportunity to conduct research at Lake Kurilskoye. We thank the employees of KamchatNIRO, the Kronotsky State Natural Biosphere Reserve, and SIEE RAS who assisted our study on various work stages.

The collection of field material was supported by the Basic Research Program of the Presidium of the Russian Academy of Sciences "Biodiversity of Natural Systems"; analysis of the field material and manuscript preparation was supported by the Russian Science Foundation, project no. 14-14-01171 "Relationship between Migrations and Morphogenesis in Juvenile Fish and Lampreys."

Open Access. This article is distributed under the terms of the Creative Commons Attribution 4.0 International License (http://creativecommons.org/licenses/ by/4.0/), which permits unrestricted use, distribution, and reproduction in any medium, provided you give appropriate credit to the original author(s) and the source, provide a link to the Creative Commons license, and indicate if changes were made.

\section{REFERENCES}

Akulin, V.N., Seasonal dynamics of the fat content in juveniles of the sockeye salmon and food zooplankton from the Dal'nee Lake, Izv. Tikhookean. Nauchno-Issled. Inst. Rybn. Khoz. Okeanogr., 1968, vol. 64, pp. 81-90.
Bodznick, D., Water source preference and lakeward migration of sockeye salmon fry (Oncorhynchus nerka), $J$. Comp. Physiol., 1978, vol. 127, pp. 139-146.

Brannon, E.L., Mechanisms controlling migration of sockeye salmon fry, Int. Pac. Salmon Fish. Comm. Bull., 1972, no. 21.

Brett, J.R. and Glass, N.R., Metabolic rates and critical swimming speeds of sockeye salmon (Oncorhynchus nerka) in relation to size and temperature, J. Fish. Res. Board Can., 1973, vol. 30, pp. 379-387.

Bugaev, V.F., Aziatskaya nerka (presnovodnyi period zhizni, struktura lokal'nykh stad, dinamika chislennosti) (Asian Sockeye Salmon: Freshwater Life Period, Structure of Local Herds, and Population Dynamics), Moscow: Kolos, 1995.

Bugaev, V.F. and Kirichenko, V.E., Nagul'no-nerestovye ozera aziatskoi nerki (vklyuchaya nekotorye drugie vodoemy areala) (Fattening and Spawning Lakes of Asian Sockeye Salmon: Including Some Other Reservoirs of the Range), Petropavlovsk-Kamchatskii: Kamchatpress, 2008.

Bugaev, V.F., Maslov, A.V., and Dubynin, V.A., Ozernovskaya nerka (biologiya, chislennost', promysel) (Ozernovskaya Sockeye Salmon: Biology, Population, and Fishery), Petropavlovsk-Kamchatskii: Kamchatpress, 2009.

Byrne, J.E., The effects of photoperiods and temperature on the daily patterns of locomotor activity in juvenile sockeye salmon (Oncorhynchus nerka), PhD Thesis, Vancouver: Univ. Br. Columbia, 1968.

Egorova, T.V., Distribution and development of sockeye salmon in the Ozernaya River basin, Izv. Tikhookean. Nauchno-Issled. Inst. Rybn. Khoz. Okeanogr., 1970, vol. 73, pp. 39-53.

Hartman, W.L. and Raleigh, R.F., Tributary homing of sockeye salmon at Brooks and Karluk Lakes, Alaska, $J$. Fish. Res. Board Can., 1964, vol. 21, no. 3, pp. 485-504.

Hartman, W.L., Heard, W.R., and Drucker, B., Migratory behavior of sockeye salmon fry and smolts, J. Fish. Res. Board Can., 1967, vol. 24, no. 10, pp. 2069-2099.

Hendry, A.P., Leonetti, F.E., and Quinn, T.P., Spatial and temporal isolating mechanisms: the formation of discrete breeding aggregations of sockeye salmon (Oncorhynchus nerka), Can. J. Zool., 1995, vol. 73, pp. 339-352.

Hensleigh, J.E. and Hendry, A.P., Rheotactic response of fry from beach-spawning populations of sockeye salmon: evolution after selection is relaxed, Can. J. Zool., 1998, vol. 76, pp. 2186-2193.

Khrustaleva, A.M., Kompleksnyi metod differentsiatsii nerki (Oncorhynchus nerka) aziarskikh stran (Complex Method of Differentiation of Asian Sockeye Salmon (Oncorhynchus nerka)), Moscow: VNIRO, 2007.

Kirillova, E.A. and Pavlov, D.S., Migration of first-year juveniles of the sockeye salmon Oncorhynchus nerka and Dolly Varden char Salvelinus malma in the waterbodies of the Kuril'skoe Lake, in Chteniya pamyati V.Ya. Levanidova (Vladimir Ya. Levanidov's Biennial Memorial Meetings), Vladivostok: Dal'nauka, 2011, no. 5, pp. 209-217.

Kirillova, E.A., Lepskaya, E.V., and Kirillov, P.I., First settlement of the yearly juveniles of the Dolly Varden char Salvelinus malma and sockeye salmon Oncorhynchus nerka in Zolotoi Klyuch spring (Kuril'skoe Lake basin), Materialy XI mezhdunarodnoi konferentsii "Sokhranenie bioraznoobraziya Kamchatki i prilegayushchikh morei” (Proc. XI Int. 
Conf. "Conservation of Biological Diversity of Kamchatka and Adjacent Seas"), Petropavlovsk-Kamchatskii: Kamchatpress, 2010, pp. 266-269.

Krokhin, E.M. and Krogius, F.V., Description of Kuril'skoe Lake and biology of the sockeye salmon Oncorhynchus nerka (Walb.) in its basin, in Trudy Tikhookeanskoi komissii. Tom IV. Kuril'skoe ozero (Transactions of the Pacific Commission, Vol. IV: Kuril'skoe Lake), Moscow: Akad. Nauk SSSR, 1937.

McCart, P., Behavior and ecology of sockeye salmon fry in the Babine River, J. Fish. Res. Board Can., 1967, vol. 24, no. 2, pp. 375-428.

Metodicheskoe posobie po izucheniyu pitaniya i pishchevykh otnoshenii ryb v estestvennykh usloviyakh (Methodological Manual for Analysis of Feeding and Food Chains of Fishes in Nature), Moscow: Nauka, 1974.

Ostroumov, A.G., The results of aerovisual registration and aeroimaging of the sockeye salmon and its spawning sites in the Kuril'skoe Lake basin, Izv. Tikhookean. NauchnoIssled. Inst. Rybn. Khoz. Okeanogr., 1970, vol. 78, pp. 17-32. Pavlov, D.S., Biologicheskie osnovy upravleniya povedeniem ryb v potoke vody (Biological Principles of the Control of Fish Behavior in Water Flow), Moscow: Nauka, 1979.

Pavlov, D.S. and Kasumyan, A.O., Patterns and mechanisms of schooling behavior in fish: a review, J. Ichthyol., 2000, vol. 40, no. 2, pp. S163-S231.

Pavlov, D.S., Kirillova, E.A., and Kirillov, P.I., Downstream migration of juveniles of salmon fishes in the Utkholok River and its tributaries (northwestern Kamchatka), 1. Downstream migration of first-year juveniles, Izv. Tikhookean. Nauchno-Issled. Inst. Rybn. Khoz. Okeanogr., 2010, vol. 163, pp. 3-44.

Pavlov, D.S., Nemova, N.N., Kirillova, E.A., Kirillov, P.I., Nefedova, Z.A., and Murzina, S.A., Lipid content in the young-of-the-year sockeye salmon Oncorhynchus nerka during feeding migration (the Ozernaya River, Western Kamchatka), Dokl. Biol. Sci., 2012, vol. 445, no. 1, pp. 235238.

Pavlov, D.S., Zvezdin, A.O., and Kostin, V.V., Rheoreaction type of early juveniles of sockeye salmon Oncorhynchus nerka in the Ozernaya River and Lake Kurilskoye, J. Ichthyol., 2013, vol. 53, no. 1, pp. 70-78.

Pavlov, D.S., Kirillova, E.A., Kirillov, P.I., and Nezdolij, V.K., Downstream migration, behavior, and distribution of fish fry in the lower reaches of the Ozernaya River (Southwestern Kamchatka), Biol. Bull., 2015, vol. 42, no. 1, pp. 43-53. Pil'ganchuk, O.A., Genetic structure of the sockeye salmon, Oncorhynchus nerka (Walbaum) from Kamchatka Peninsula, Extended Abstract of Cand. Sci. (Biol.) Dissertation, Petropavlovsk-Kamchatskii: Kamchat. NauchnoIssled. Inst. Rybn. Khoz. Okeanogr., 2014.

Pil'ganchuk, O.A., Varnavskaya, N.V., and Bichem, T.D., Characteristic of intrapopulation structure of the sockeye salmon from the Kuril'skoe Lake and Kamchatka River by variability of microsatellite nuclear DNA, in Issledovaniya vodnykh biologicheskikh resursov Kamchatki i severo-zapadnoi chasti Tikhogo okeana (Study of Aquatic Biological Resources of Kamchatka and Northwestern Part of Pacific Ocean), Petropavlovsk-Kamchatskii: Kamchat. NauchnoIssled. Inst. Rybn. Khoz. Okeanogr., 2010, no. 18, pp. 2837.

Pon, L.B., Hinch, S.G., Wagner, G.N., et al., Swimming performance and morphology of juvenile sockeye salmon, Oncorhynchus nerka: comparison of inlet and outlet fry populations, Environ. Biol. Fish., 2007, vol. 78, pp. 257269.

Quinn, T.P., The Behavior and Ecology of Pacific Salmon and Trout, Washington: Amer. Fish. Soc., Univ. Wash. Press, 2005.

Raleigh, R.F., Innate control of migrations of salmon and trout fry from natal gravels to rearing areas, Ecology, 1971, vol. 52, no. 2, pp. 291-297.

Smirnov, A.I., Biologiya, razmnozhenie $i$ razvitie tikhookeanskikh lososei (Biology, Reproduction, and Development of Pacific Salmons), Moscow: Mosk. Gos. Univ., 1975.

Varnavskaya, N.V., Geneticheskaya differentsiatsiya populyatsii tikhookeanskikh lososei (Genetic Differentiation of Populations of Pacific Salmons), Petropavlovsk-Kamchatskii: Kamchat. Nauchno-Issled. Inst. Rybn. Khoz. Okeanogr., 2006.

Zvezdin, A.O., Pavlov, D.S., and Kostin, V.V., On the mechanism of orientation and navigation of sockeye salmon underyearlings (Oncorhynchus nerka Walb.) during feeding migration in the inlet-lake-outlet system, Inland Water Biol., 2015, vol. 8, no. 3, pp. 287-295.

Translated by A. Lisenkova 